\title{
Recovery of Platinum Group Metals from Spent Catalysts Using Iron Chloride Vapor Treatment
}

\begin{abstract}
YU-KI TANINOUCHI and TORU H. OKABE
The recovery of platinum group metals (PGMs) from spent automobile catalysts is a difficult process because of their relatively low contents in the scrap. In this study, to improve the efficiency of the existing recycling techniques, a novel physical concentration method involving treatment with $\mathrm{FeCl}_{2}$ vapor has been examined. The reactions occurring between typical catalyst components and $\mathrm{FeCl}_{2}$ vapor are discussed from the thermodynamic point of view, and the validity of the proposed technique was experimentally verified. The obtained results indicate that the vapor treatment at around $1200 \mathrm{~K}\left(927^{\circ} \mathrm{C}\right)$ can effectively alloy PGMs ( $\mathrm{Pt}$, Pd, and $\mathrm{Rh}$ ) with $\mathrm{Fe}$, resulting in the formation of a ferromagnetic alloy. It was also confirmed that cordierite and alumina (the major catalyst components) remained unreacted after the vapor treatment, while ceria species were converted into oxychlorides. The samples simulating the automobile catalyst were also subjected to magnetic separation after the treatment with $\mathrm{FeCl}_{2}$ vapor; as a result, PGMs were successfully extracted and concentrated in the form of a magnetic powder. Thus, the $\mathrm{FeCl}_{2}$ vapor treatment followed by magnetic separation can be utilized for recovering PGMs directly from spent catalysts as an effective pretreatment for the currently used recycling methods.
\end{abstract}

https://doi.org/10.1007/s11663-018-1269-9

(C) The Minerals, Metals \& Materials Society and ASM International 2018

\section{INTRODUCTION}

Platinum group metals (PGMs) are expensive and relatively scarce elements in the Earth's crust. The mineral resources of PGMs are predominately localized in South Africa and Russia. ${ }^{[1-4]}$ Furthermore, their extraction and subsequent treatment generate large amounts of waste and consume a lot of energy. PGMs are widely used in various industrial applications because of their unique catalytic properties and excellent heat and corrosion resistances. In particular, automobile catalysts account for a large fraction of the global demand for $\mathrm{Pt}, \mathrm{Pd}$, and $\mathrm{Rh} .{ }^{[1]}$ Therefore, the recovery of PGMs from spent automobile catalysts is important not only in terms of ensuring their steady supply, but also minimizing the environmental burden.

The recycling of PGMs from spent catalysts has been actively practiced by many smelting and recycling companies. However, the efficient recovery of these metals is difficult because of their relatively low concentrations in the scrap and high chemical stability.

YU-KI TANINOUCHI and TORU H. OKABE are with the Institute of Industrial Science, The University of Tokyo, 4-6-1 Komaba, Meguro-ku, Tokyo 153-8505, Japan. Contact e-mail: taninou@ iis.u-tokyo.ac.jp

Manuscript submitted December 18, 2017.

Article published online May 7, 2018.
Automobile catalysts mostly consist of honeycomb-structured ceramic substrates with porous catalyst layer. The ceramic substrates are composed of cordierite $\left(\mathrm{Mg}_{2} \mathrm{Al}_{4} \mathrm{Si}_{5} \mathrm{O}_{18}\right)$ or similar chemically stable oxides. The catalyst layers that support fine PGM particles consist of alumina $\left(\mathrm{Al}_{2} \mathrm{O}_{3}\right)$ and other oxides such as ceria $\left(\mathrm{CeO}_{2}\right)$ and zirconia $\left(\mathrm{ZrO}_{2}\right)$. The total concentration of PGMs in the catalysts is approximately $0.05-0.5$ mass pct $(500-5000 \mathrm{ppm}){ }^{[5]}$

Usually, the catalysts recovered from used automobiles are first mechanically pulverized to evaluate their PGM contents and then subjected to pyrometallurgical and/or hydrometallurgical processes for PGM extraction (see Figure 1)..$^{[2-5]}$ In commercial applications, pulverized catalysts are often smelted with a collector metal such as liquid $\mathrm{Fe}$ or $\mathrm{Cu}$; hereby, $\mathrm{PGMs}$ are concentrated in the metallic phase, while the ceramic components of the spent catalysts are removed as slag waste. $^{[6,7]}$ Subsequently, the PGMs extracted in the collector metal are dissolved in an aqueous solution followed by their separation and purification using various techniques such as solvent extraction, precipitation, and ion exchange. ${ }^{[8,9]}$ The benefits of the pyrometallurgical processing method include large PGM recovery rates and high throughput. However, its practical implementation requires the use of largescale equipment and high amount of energy. It should also be noted that PGMs could be dissolved directly from spent catalysts in strong oxidizing acids, such as 
aqua regia and hydrochloric acid with chlorine gas, which is typically performed using a small-scale plant with relatively low energy consumption. However, the applicability of this method is often limited by the low PGM recovery rates, longer processing times, and generation of large volumes of toxic waste solutions and gases.

A physical separation pretreatment aimed at concentrating PGMs directly from spent catalysts can potentially improve the efficiency and throughput of the existing recycling processes. To achieve this goal, various techniques such as magnetic separation, ${ }^{[10,11]}$ flotation, ${ }^{[11,12]}$ selective grinding followed by size separation, ${ }^{[13,14]}$ selective grinding after a heating/quenching treatment, ${ }^{[15]}$ and physical separation methods involving simple chemical pretreatments such as alloying, sulfurization, and plating ${ }^{[16-20]}$ have been proposed and studied. However, these techniques are either in the developmental stage or not practically feasible for the industrial use.

The objective of this study is to investigate the feasibility and industrial applicability of the novel physical concentration process illustrated in Figure 1. The proposed method involves a chemical pretreatment stage and uses the concept outlined in the patent

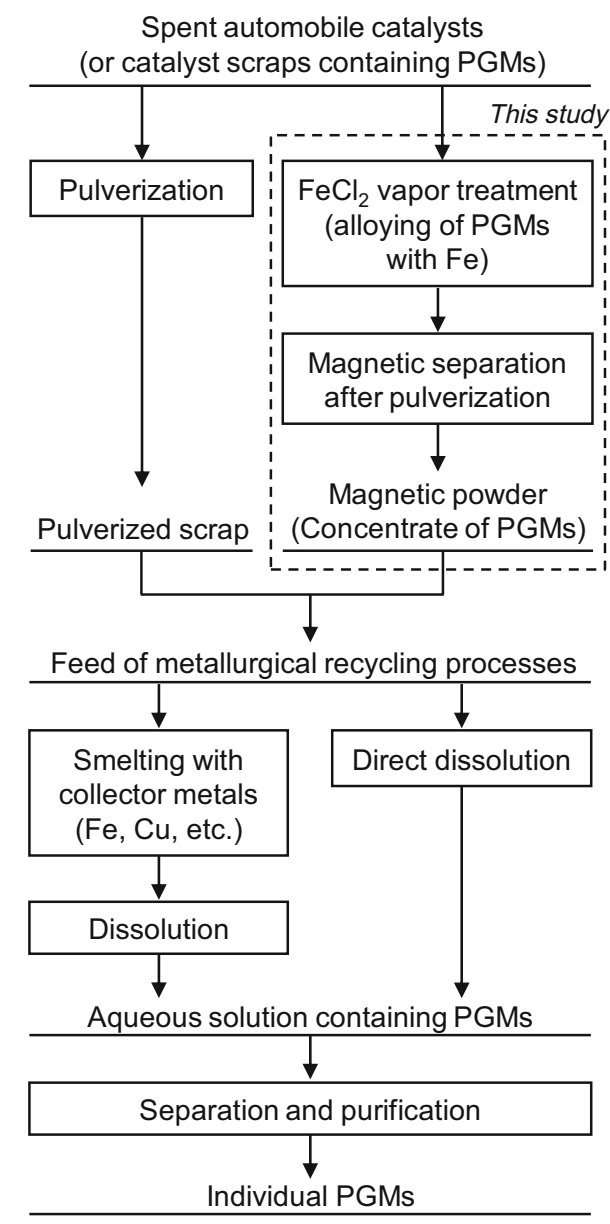

Fig. 1-Diagram describing the novel physical concentration method proposed in this study and common procedure for recovering PGMs from spent catalysts. invented by Okabe and Mitsui. ${ }^{[16]}$ For effectively concentrating PGMs via magnetic separation, they are converted into ferromagnetic Fe-PGM alloys through the reaction with $\mathrm{FeCl}_{2}$ vapor. It is also notable that the dissolution of PGMs can be promoted by alloying with less noble metals ${ }^{[2,21,22]}$; thus, alloying with Fe would be useful not only for magnetically separating PGMs, but also for facilitating their dissolution in acid.

In a previous study, we examined possible reactions between pure $\mathrm{Pt}$ and $\mathrm{FeCl}_{x}(x=2,3) .{ }^{[20]}$ It was found that $\mathrm{Pt}$ metal could be effectively converted into a ferromagnetic alloy through its reaction with $\mathrm{FeCl}_{2}$ in the presence of metallic $\mathrm{Fe}$, and the corresponding alloying reaction was represented by the disproportionation of $\mathrm{FeCl}_{2}$ vapor. The modern automobile catalysts also contain other PGMs such as Pd and Rh, while their major components consist of various oxides (such as cordierite and $\mathrm{Al}_{2} \mathrm{O}_{3}$ ). Therefore, in this study, to further investigate the proposed route, the reactivities of these compounds during the $\mathrm{FeCl}_{2}$ vapor treatment were examined theoretically and experimentally. Moreover, the magnetic concentration of PGMs was demonstrated using the samples simulating an automobile catalyst.

\section{TREATMENT WITH IRON CHLORIDE VAPOR}

\section{A. Theoretical Background}

Figure 2 outlines the proposed $\mathrm{FeCl}_{2}$ vapor treatment procedure. The volatilities of $\mathrm{FeCl}_{x}$ species are sufficiently high; in particular, the vapor pressures of $\mathrm{FeCl}_{2}$ and $\mathrm{FeCl}_{3}$ exceed $10^{-1}$ atm at temperatures above $1090 \mathrm{~K}$ and $540 \mathrm{~K}\left(817^{\circ} \mathrm{C}\right.$ and $\left.267^{\circ} \mathrm{C}\right)$, respectively. ${ }^{[23]}$ Thus, $\mathrm{FeCl}_{2}$ vapor can be effectively supplied to the PGMs located on the complex porous surfaces of catalysts by heating its source. The utilized reaction system is loaded with metallic Fe characterized by high affinity to PGMs (the treatment chamber either is fabricated from steel or contains pieces of metallic $\mathrm{Fe}$ ). As a result, under suitable conditions, the gaseous phase acts as a medium that transports Fe from the metallic

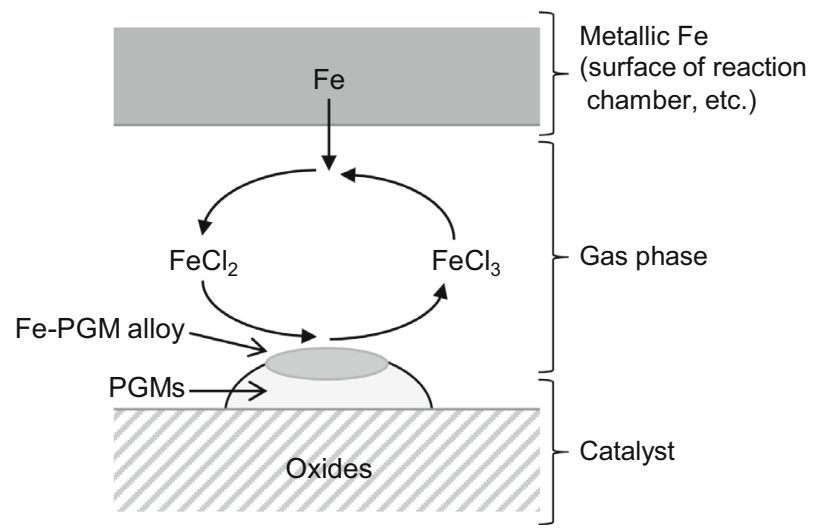

Fig. 2-Schematic illustration of the $\mathrm{FeCl}_{2}$ vapor treatment procedure. The PGMs in spent catalysts are alloyed with Fe through the disproportionation of $\mathrm{FeCl}_{2}$ vapor. 
phase to the PGMs, and alloys them together via the following disproportionation reaction ${ }^{[20]}$ :

$$
3 \mathrm{FeCl}_{2}(g) \rightarrow \mathrm{Fe}(s, \text { in } \mathrm{PGM})+2 \mathrm{FeCl}_{3}(g)
$$

$$
\begin{aligned}
& 3 \mathrm{FeCl}_{2}(g)=\mathrm{Fe}(s)+2 \mathrm{FeCl}_{3}(g) \\
& \Delta G_{(2)}^{\circ}=126 \mathrm{~kJ} \text { at } 1200 \mathrm{~K}\left(927^{\circ} \mathrm{C}\right),{ }^{[23]}
\end{aligned}
$$

where $\Delta G_{(2)}^{\circ}$ denotes the standard Gibbs energy change of reaction [2]. The $\mathrm{FeCl}_{3}$ molecules generated by the disproportionation reaction diffuse into the gas phase and then react with metallic $\mathrm{Fe}$ to regenerate $\mathrm{FeCl}_{2}$.

$$
\mathrm{Fe}(s)+2 \mathrm{FeCl}_{3}(g) \rightarrow 3 \mathrm{FeCl}_{2}(g)
$$

The overall reaction can be expressed as follows:

$$
\mathrm{Fe}(s) \rightarrow \mathrm{Fe}(s, \text { in } \mathrm{PGM}) .
$$

After the vapor treatment, $\mathrm{FeCl}_{x}$ species may attach to the scrap surface. However, they can be further separated and recovered from the scrap via evaporation without producing a toxic waste solution. If all PGMs are alloyed through the described mechanism while the ceramic components remain unreacted, the supplied $\mathrm{FeCl}_{2}$ species can be conserved and recycled for the subsequent use.

\section{B. Thermodynamic Considerations}

In this section, the reactions occurring during the $\mathrm{FeCl}_{2}$ vapor treatment are further examined at a temperature of $1200 \mathrm{~K}\left(927^{\circ} \mathrm{C}\right)$, which was effectively used for alloying $\mathrm{Pt}$ samples with $\mathrm{Fe}$ in a previous study. ${ }^{[20]}$ At this temperature, $\mathrm{FeCl}_{2}$ is a liquid, and its vapor pressure can be as high as $3.2 \times 10^{-1}$ atm. $^{[23]}$

In Figure 3, the chemical potentials of chlorine $\left(p_{\mathrm{Cl}_{2}}\right)$ corresponding to the $\mathrm{Pt} / \mathrm{PtCl}, \mathrm{Pd} / \mathrm{PdCl}_{2}$, and $\mathrm{Rh} / \mathrm{RhCl}{ }_{3}$ equilibria are listed on the potential diagram of the $\mathrm{Fe}-\mathrm{Cl}$ system. The thermodynamic data provided in Reference 23 were used during calculations. At around $1200 \mathrm{~K}\left(927{ }^{\circ} \mathrm{C}\right)$, the $p_{\mathrm{Cl}_{2}}$ corresponding to the equilibrium between PGMs and their chlorides is significantly higher than the values obtained at the $\mathrm{Fe} / \mathrm{FeCl}_{2}$ and $\mathrm{FeCl}_{2} / \mathrm{FeCl}_{3}$ equilibria. Thus, it can be assumed that $\mathrm{Pt}$, $\mathrm{Pd}$, and $\mathrm{Rh}$ are not chlorinated during the $\mathrm{FeCl}_{2}$ vapor treatment.

Figure 4 shows the phase diagrams of the Fe-Pt, $\mathrm{Fe}-\mathrm{Pd}$, and Fe-Rh systems. ${ }^{[2,25]}$ The $\alpha$-phase, which is a solid solution with a body-centered cubic structure, exhibits ferromagnetic properties at ambient temperature (around $298 \mathrm{~K}$ ). Furthermore, the $\gamma_{1}-\mathrm{Fe}_{3} \mathrm{Pt}$ and $\gamma_{2}$-FePt phases of the Fe-Pt system, $\gamma_{1}-\mathrm{FePd}$ and $\gamma_{2}-\mathrm{FePd}_{3}$ phases of the Fe-Pd system, and $\alpha^{\prime}-(\mathrm{Fe}, \mathrm{Rh})$ phase of the Fe-Rh system can be also ferromagnetic at such a temperature. To achieve efficient recovery of PGMs from the catalyst scrap by magnetic separation, they should be converted into these ferromagnetic alloys through vapor treatment. For example, if the $\mathrm{Fe}$ concentration in $\mathrm{Pd}$ exceeds approximately $15 \mathrm{~mol} \mathrm{pct}$

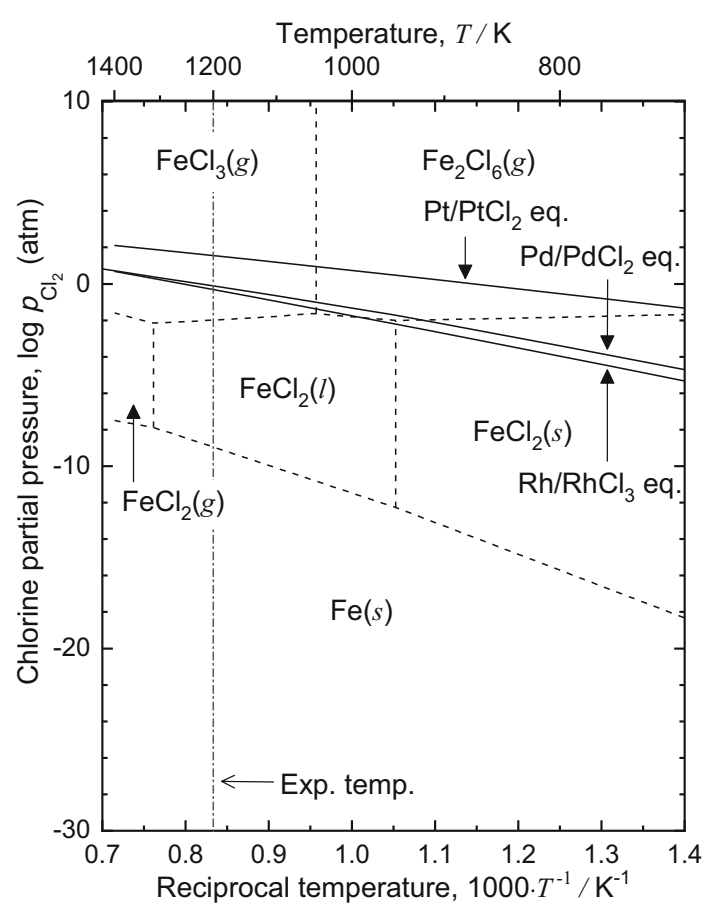

Fig. 3-Chemical potentials of chlorine corresponding to the equilibria between PGMs and their chlorides as functions of temperature. The chemical potential diagram of the $\mathrm{Fe}-\mathrm{Cl}$ system is plotted as the dotted line. The thermodynamic data reported in Ref. [23] were used.

after performing reaction [1] at $1200 \mathrm{~K}\left(927^{\circ} \mathrm{C}\right)$, ferromagnetic Fe-Pd alloys $\left(\alpha-(\mathrm{Fe}, \mathrm{Pd}), \gamma_{1}-\mathrm{FePd}\right.$, and/or $\gamma_{2}-\mathrm{FePd}_{3}$ ) can be formed during cooling or by annealing at intermediate temperatures. To obtain ferromagnetic $\mathrm{Fe}-\mathrm{Rh}$ alloys at ambient temperature (such as $\alpha-(\mathrm{Fe}, \mathrm{Rh})$ and/or $\left.\alpha^{\prime}-(\mathrm{Fe}, \mathrm{Rh})\right)$, the $\mathrm{Fe}$ concentration in $\mathrm{Rh}$ should be increased above approximately $40 \mathrm{~mol}$ pet.

From the viewpoint of equilibrium, the alloying of PGMs proceeds until the activity of $\mathrm{Fe}\left(a_{\mathrm{Fe}}\right)$ in the Fe-PGM alloy becomes equal to the $a_{\mathrm{Fe}}$ of the reaction system. Since the utilized reaction system contains excess amounts of metallic $\mathrm{Fe}$, its $a_{\mathrm{Fe}}$ is almost unity. Thus, the proposed vapor treatment can potentially increase the Fe concentration in PGMs to an amount sufficient for the formation of ferromagnetic alloys. In order to consider the reaction rate of PGM alloying, the relationship between $a_{\mathrm{Fe}}$ and the equilibrium partial pressure of $\mathrm{FeCl}_{3}\left(p_{\mathrm{FeCl}_{3}}\right)$ under the specified $p_{\mathrm{FeCl}_{2}}$ was calculated at $1200 \mathrm{~K}\left(927^{\circ} \mathrm{C}\right)$ using the thermodynamic data reported in Reference 23. The result is shown in Figure 5. The equilibrium $p_{\mathrm{FeCl}_{3}}$ decreases with an increase in $a_{\mathrm{Fe}}$ (or with alloying $\mathrm{Fe}$ ). When the $p_{\mathrm{FeCl}_{2}}$ is $3.2 \times 10^{-1}$ atm (corresponding to the saturated vapor pressure of $\mathrm{FeCl}_{2}$ ), the equilibrium $p_{\mathrm{FeCl}_{3}}$ of the produced Fe-PGM alloy is higher than $3 \times 10^{-4} \mathrm{~atm}$ and can be as high as $1 \times 10^{-3} \mathrm{~atm}$ at $a_{\mathrm{Fe}}=1 \times 10^{-1}$ (where $\gamma_{2}$-FePt phase is stable in the Fe-Pt system ${ }^{[26]}$ ). Thus, the reaction of $\mathrm{FeCl}_{2}$ vapor with PGMs can proceed relatively fast.

In general, the cordierite and $\mathrm{Al}_{2} \mathrm{O}_{3}$ phases are the major components of honeycomb-structured substrate and porous catalyst layer, respectively. In order to 
(a)

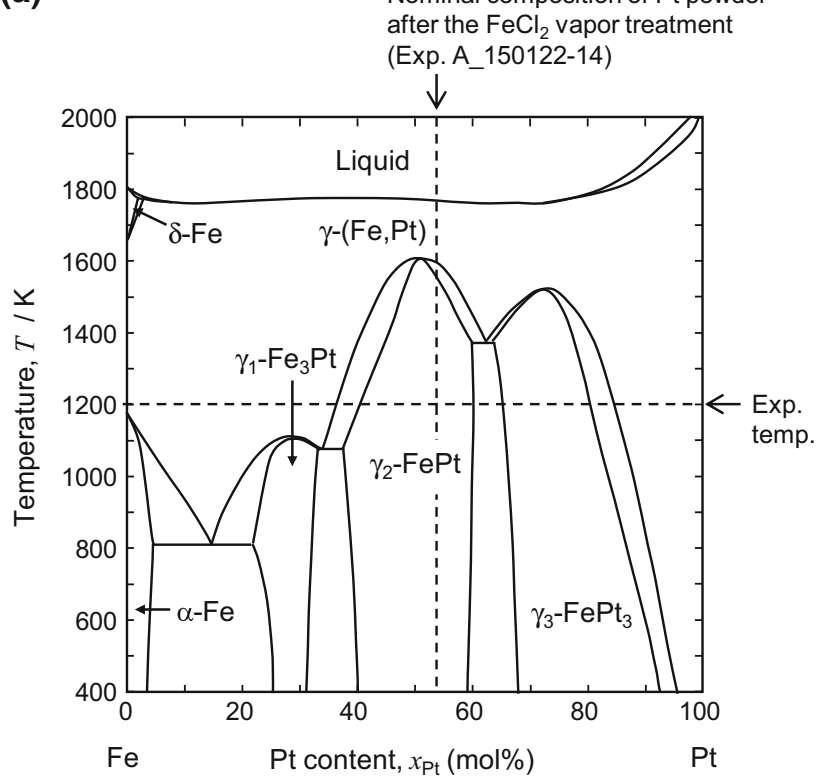

(b)

Nominal composition of $\mathrm{Pd}$ powder after the $\mathrm{FeCl}_{2}$ vapor treatment

(Exp. A_150122-14)

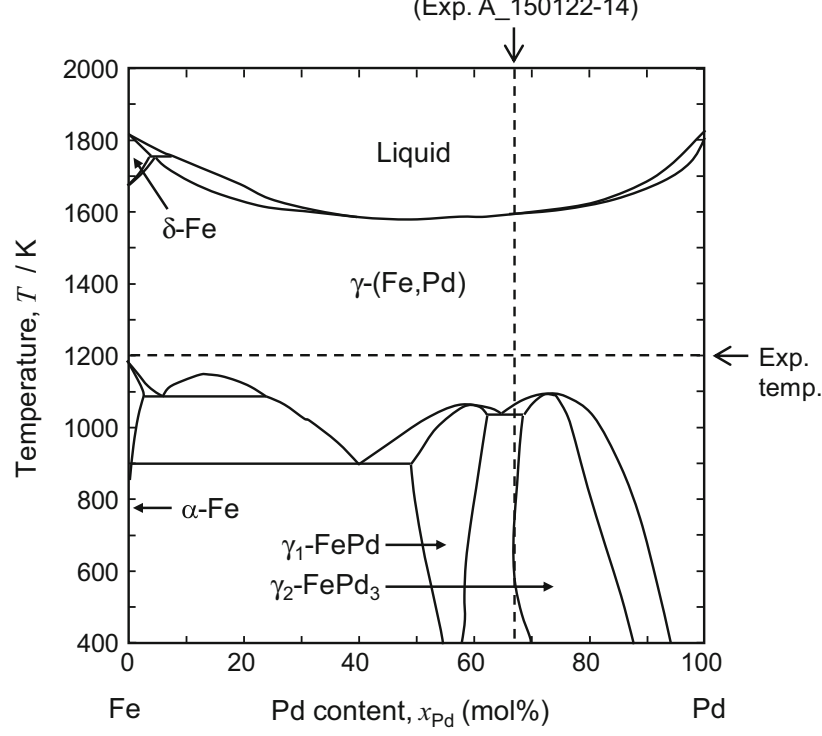

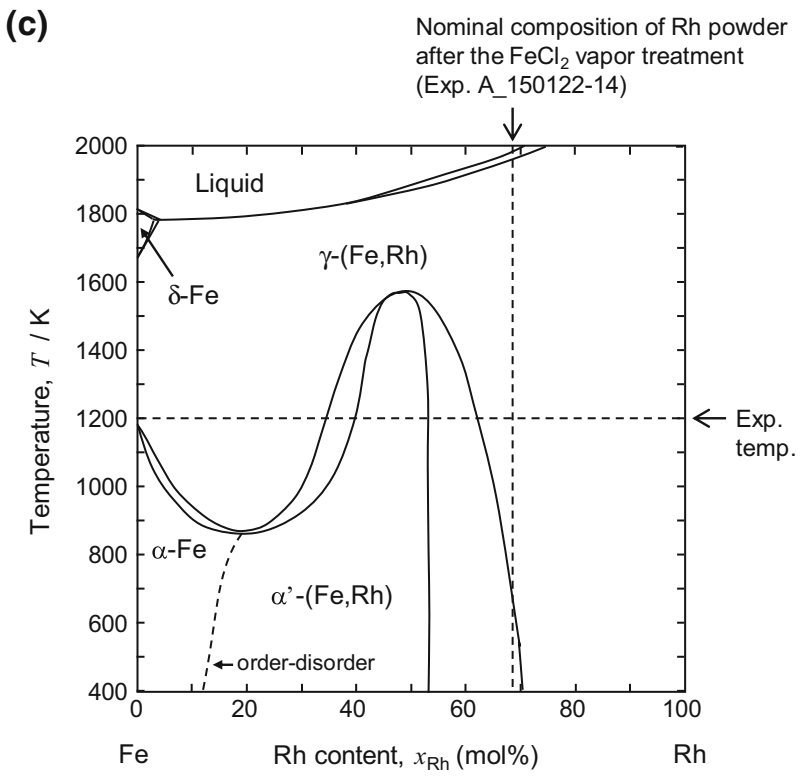

Fig. 4-Phase diagrams of the (a) Fe-Pt, (b) Fe-Pd, and (c) Fe-Rh systems adapted from Refs. [24] and [25]. The phases denoted by $\gamma_{i}$ correspond to fcc-based ordered structures.

analyze the reactivities of these oxides during the $\mathrm{FeCl}_{2}$ vapor treatment, chemical potential diagrams of the $\mathrm{M}-\mathrm{Cl}-\mathrm{O}$ system (M: $\mathrm{Al}, \mathrm{Mg}, \mathrm{Si}$, and $\mathrm{Fe}$ ) were constructed at $1200 \mathrm{~K}\left(927^{\circ} \mathrm{C}\right)$ using the thermodynamic data reported in the literature. ${ }^{[23]}$

Figure 6(a) is constructed by overlapping the chemical potential diagram of the Al-Cl-O system with that of the Fe-Cl-O system. The diagram is described using the logarithms of the partial pressure of chlorine $\left(p_{\mathrm{Cl}_{2}}\right)$ and partial pressure of oxygen $\left(p_{\mathrm{O}_{2}}\right)$ as the abscissa and ordinate, respectively. During the vapor treatment, sufficient amounts of $\mathrm{Fe}$ and $\mathrm{FeCl}_{2}$ are present in the reaction system, and the magnitude of $p_{\mathrm{FeCl}_{2}}$ corresponds to the saturated vapor pressure of liquid $\mathrm{FeCl}_{2}$. In this case, the $p_{\mathrm{Cl}_{2}}$ and $p_{\mathrm{O}_{2}}$ of the reaction system can be determined by the $\mathrm{Fe} / \mathrm{FeCl}_{2}$ and $\mathrm{Fe} / \mathrm{FeO}$ equilibria, respectively. Therefore, the chemical potential of the reaction system is located near the potential point $\alpha$ in the figure. At this chemical potential, the $\mathrm{Al}_{2} \mathrm{O}_{3}$ phase is thermodynamically stable, which indicates that $\mathrm{Al}_{2} \mathrm{O}_{3}$ species present in the catalyst scrap likely remain unreacted during the vapor treatment.

In Figure 6(b), the chemical potential diagram of the $\mathrm{Mg}-\mathrm{O}-\mathrm{Cl}$ system is overlaid on that of the $\mathrm{Fe}-\mathrm{O}-\mathrm{Cl}$ system. Meanwhile, in Figure 6(c), the chemical potential diagram of the $\mathrm{Si}-\mathrm{O}-\mathrm{Cl}$ system is overlaid on that of 
the $\mathrm{Fe}-\mathrm{O}-\mathrm{Cl}$ system. At the potential point $\alpha$, both the $\mathrm{MgO}$ and $\mathrm{SiO}_{2}$ phases are stable. Since cordierite is a complex oxide of $\mathrm{Al}_{2} \mathrm{O}_{3}, \mathrm{MgO}$, and $\mathrm{SiO}_{2}$, it is expected not to react with $\mathrm{FeCl}_{2}$ vapor.

The reactivities of $\mathrm{ZrO}_{2}, \mathrm{La}_{2} \mathrm{O}_{3}$, and $\mathrm{CeO}_{2}$ species are also analyzed, because these oxides and/or their solid solutions are often contained in the porous catalyst layer of automobile catalysts. The chemical potential diagrams shown in Figure 7 were constructed at $1200 \mathrm{~K}$ $\left(927^{\circ} \mathrm{C}\right)$ using the thermodynamic data reported in the literature. ${ }^{[23]}$ The standard Gibbs energy of formation of $\mathrm{CeOCl}$ was estimated from its standard enthalpy of formation at $298 \mathrm{~K}\left(25^{\circ} \mathrm{C}\right)^{[27]}$ and the Gibbs energy function of the formation of $\mathrm{LaOCl}^{[23]}$ (the details of the utilized procedure are provided elsewhere ${ }^{[28]}$ ).

As shown in Figure 7(a), the $\mathrm{ZrO}_{2}$ phase is stable near the potential point $\alpha$ corresponding to the chemical potential at the $\mathrm{Fe} / \mathrm{FeCl}_{2} / \mathrm{FeO}$ equilibrium. Thus, $\mathrm{ZrO}_{2}$ species in the catalyst scrap are expected to remain unreacted during the vapor treatment. Meanwhile, the $\mathrm{La}_{2} \mathrm{O}_{3}$ and $\mathrm{CeO}_{2}$ phases are unstable at the potential point $\alpha$, as shown in Figures 7(b) and (c), respectively. Because $\mathrm{LaOCl}$ is stable at the potential point $\alpha$, the $\mathrm{La}_{2} \mathrm{O}_{3}$ species contained in the scrap are expected to react with $\mathrm{FeCl}_{2}$ vapor as follows:

$$
\begin{aligned}
& \mathrm{La}_{2} \mathrm{O}_{3}(s)+\mathrm{FeCl}_{2}(g)=2 \mathrm{LaOCl}(s)+\mathrm{FeO}(s) \\
& \Delta G_{(5)}^{\circ}=-136 \mathrm{~kJ} \text { at } 1200 \mathrm{~K}\left(927^{\circ} \mathrm{C}\right) \cdot .^{[23]}
\end{aligned}
$$

For the $\mathrm{CeO}_{2}$ species, the following reaction is expected to occur:

$$
\begin{aligned}
& \mathrm{CeO}_{2}(s)+2 \mathrm{FeCl}_{2}(g)=\mathrm{CeOCl}(s)+\mathrm{FeO}(s)+\mathrm{FeCl}_{3}(g) \\
& \Delta G_{(6)}^{\circ}=22 \mathrm{~kJ} \text { at } 1200 \mathrm{~K}\left(927^{\circ} \mathrm{C}\right) . .^{[23,27]}
\end{aligned}
$$

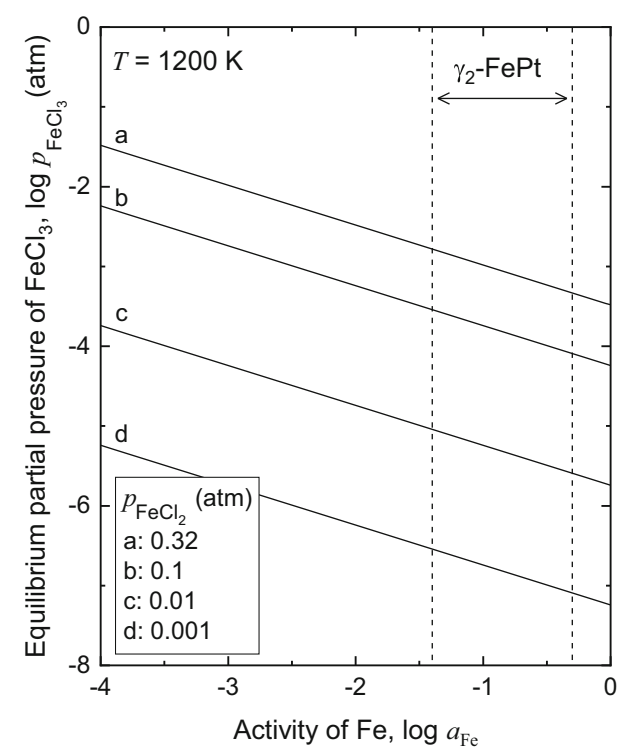

Fig. 5-Partial pressure of $\mathrm{FeCl}_{3}$ equilibrated with Fe-PGM alloy at the specified partial pressures of $\mathrm{FeCl}_{2}$ and temperature of $1200 \mathrm{~K}$ $\left(927^{\circ} \mathrm{C}\right)$. The thermodynamic data reported in Ref. [23] were used. The saturated vapor pressure of $\mathrm{FeCl}_{2}$ at $1200 \mathrm{~K}\left(927^{\circ} \mathrm{C}\right)$ is $0.32 \mathrm{~atm}$.
The gaseous $\mathrm{FeCl}_{3}$ generated by reaction [6] will react with metallic $\mathrm{Fe}$ in the reaction system.

$$
\begin{aligned}
& \mathrm{FeCl}_{3}(g)+1 / 2 \mathrm{Fe}(s)=3 / 2 \mathrm{FeCl}_{2}(g) \\
& \Delta G_{(7)}^{\circ}=-63 \mathrm{~kJ} \text { at } 1200 \mathrm{~K}\left(927^{\circ} \mathrm{C}\right) .{ }^{[23]}
\end{aligned}
$$

Thus, the overall reaction can be expressed as follows:

$$
\begin{aligned}
& \mathrm{CeO}_{2}(s)+1 / 2 \mathrm{FeCl}_{2}(g)+1 / 2 \mathrm{Fe}(s)=\mathrm{CeOCl}(s)+\mathrm{FeO}(s) \\
& \Delta G_{(8)}^{\circ}=\Delta G_{(6)}^{\circ}+\Delta G_{(7)}^{\circ}=-41 \mathrm{~kJ} \text { at } 1200 \mathrm{~K}\left(927^{\circ} \mathrm{C}\right) .{ }^{[23,27]}
\end{aligned}
$$

\section{MATERIALS AND METHODS}

\section{A. Sample Preparation}

Table I lists all the samples used in this study. Powders of PGMs ( $\mathrm{Pt}, \mathrm{Pd}$, and $\mathrm{Rh}$ ), cordierite, $\mathrm{Al}_{2} \mathrm{O}_{3}$, $\mathrm{ZrO}_{2}, \mathrm{La}_{2} \mathrm{O}_{3}$, and $\mathrm{CeO}_{2}$ were used as the starting materials during the $\mathrm{FeCl}_{2}$ vapor treatment. Furthermore, plate-type catalyst samples were prepared to simulate the automobile catalyst. Since the procedure for the preparation of the catalyst sample has been previously described in detail elsewhere, ${ }^{[17]}$ only a brief outline is provided in this study. First, Pt-, Pd-, and Rh-loaded alumina powders were synthesized by baking $\gamma-\mathrm{Al}_{2} \mathrm{O}_{3}$ powder impregnated with aqueous solutions of various PGMs and then mixed with boehmite powder and diluted aqueous solution of $\mathrm{HNO}_{3}$ to prepare slurry. The latter was coated onto an $\mathrm{Al}_{2} \mathrm{O}_{3}$ plate with an area of approximately $25 \times 25 \mathrm{~mm}^{2}$ and thickness of $0.5 \mathrm{~mm}$ and then baked at $1073 \mathrm{~K}\left(800{ }^{\circ} \mathrm{C}\right)$ for 3 hours in vacuum. The thickness of the porous catalyst layer formed on the $\mathrm{Al}_{2} \mathrm{O}_{3}$ plate was several hundred micrometers (see Figure 15(a)), and the concentration of each PGM in the catalyst samples was approximately 0.04 mass pct (see Table III).

\section{B. Experimental Procedure}

The experimental apparatus used for the $\mathrm{FeCl}_{2}$ vapor treatment is shown in Figure 8, while the masses of the feed materials are listed in Table II. The tested samples were held in a quartz crucibles, which were subsequently placed in the reaction chamber fabricated from mild steel, as shown in Figures 8(a) and (b). A mixture of Fe powder (>95 pct; Wako Pure Chemical Industries, Ltd.) and $\mathrm{FeCl}_{2}$ powder (99.9 pct; Wako Pure Chemical Industries, Ltd.) was placed at the chamber's bottom. To prevent the water adsorption by $\mathrm{FeCl}_{2}$, the mixture of $\mathrm{Fe}$ and $\mathrm{FeCl}_{2}$ was prepared inside a glove box under a high-purity $\mathrm{N}_{2}$ atmosphere. The reaction chamber was covered with a steel cap without sealing. As shown in Figure 8(c), the reaction chamber was positioned at the bottom of a vertical gas-tight quartz tube. The interior of this tube was evacuated using a rotary pump, following which the exhaust port located at the tube top was closed.

To perform the vapor treatment procedure at $1200 \mathrm{~K}$ $\left(927^{\circ} \mathrm{C}\right)$, the quartz tube containing the reaction 
(a)

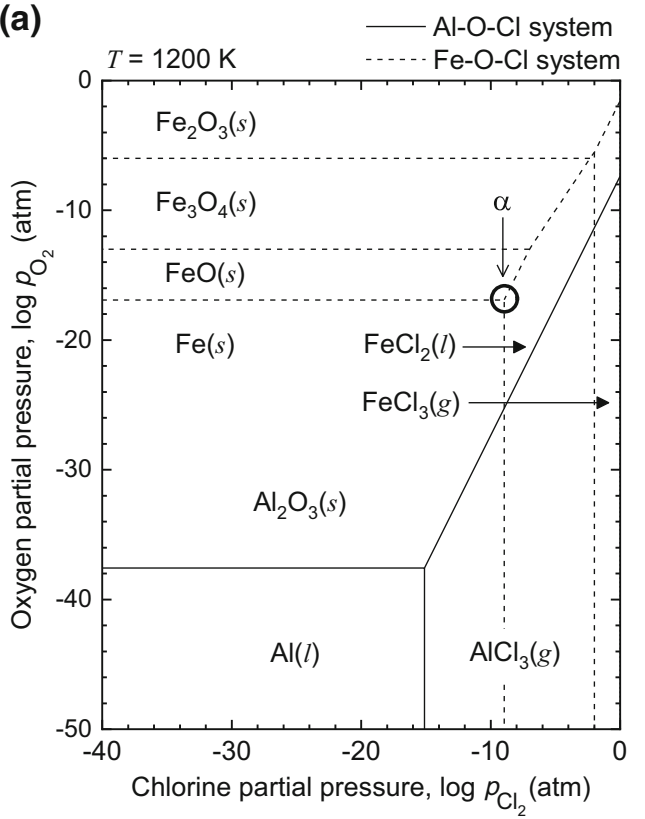

(b)

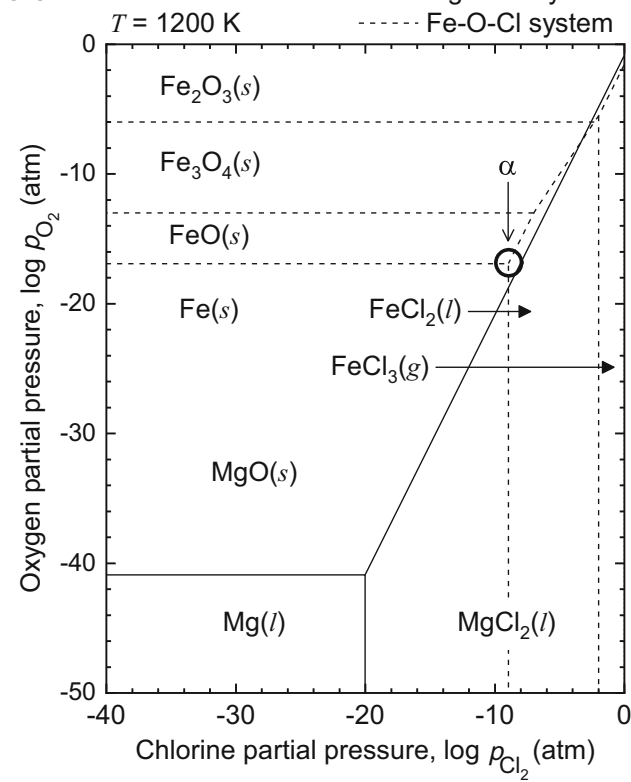

(c)

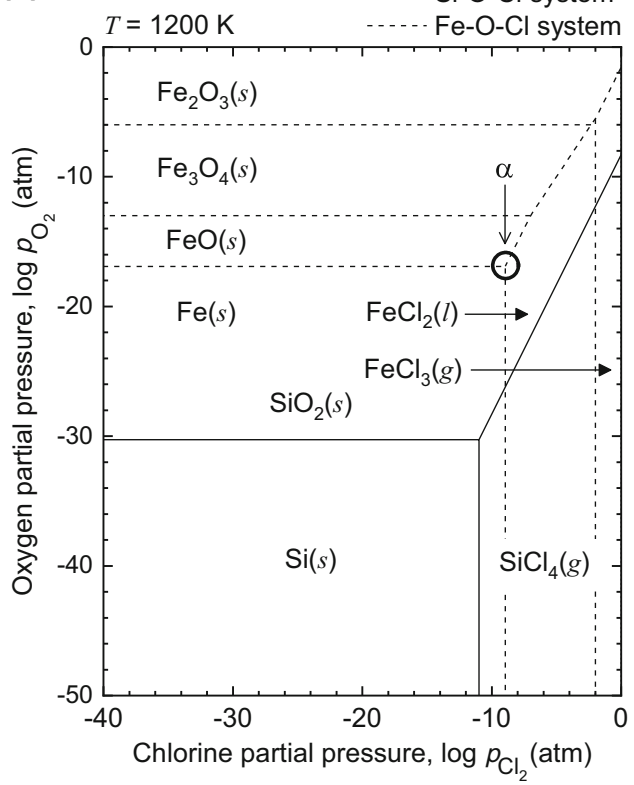

Fig. 6 - Combined chemical potential diagrams of the (a) Al-O-Cl and Fe-O-Cl, (b) $\mathrm{Mg}-\mathrm{O}-\mathrm{Cl}$ and Fe-O-Cl, and (c) Si-O-Cl and Fe-O-Cl systems constructed at $1200 \mathrm{~K}\left(927^{\circ} \mathrm{C}\right)$. The thermodynamic data reported in $\mathrm{Ref}$. [23] were used. The potential point $\alpha$ corresponds to the $\mathrm{Fe} / \mathrm{FeCl} / 2$ $\mathrm{FeO}$ equilibrium.

chamber was introduced into a preheated vertical furnace and kept there for 1.5 hours. Afterward, the quartz tube was removed from the furnace and cooled in air. Figure 9 shows the temperature profile recorded inside the quartz tube. The temperature measured at the location of the reaction chamber reached $1200 \mathrm{~K}$ $\left(927^{\circ} \mathrm{C}\right)$ after 0.5 hour and then was maintained at that level for 1 hour, as shown in Figure 9(a). During the heat treatment, the upper part of the quartz tube was kept at a lower temperature, as shown in Figure 9(b).
After the heat treatment, Ar gas or air was introduced inside the quartz tube to reach atmospheric pressure, and then the rubber plug was removed from the top of the tube. Subsequently, the samples in the reaction chamber and deposits accumulated on the inner wall of the quartz tube were recovered. The crystalline phases of the processed powder samples and deposits on the tube wall were analyzed by X-ray diffraction (XRD) using a D2 PHASER (Bruker Corporation, $\mathrm{Cu}-\mathrm{K} \alpha$ radiation). In some experiments, qualitative elemental analysis was 

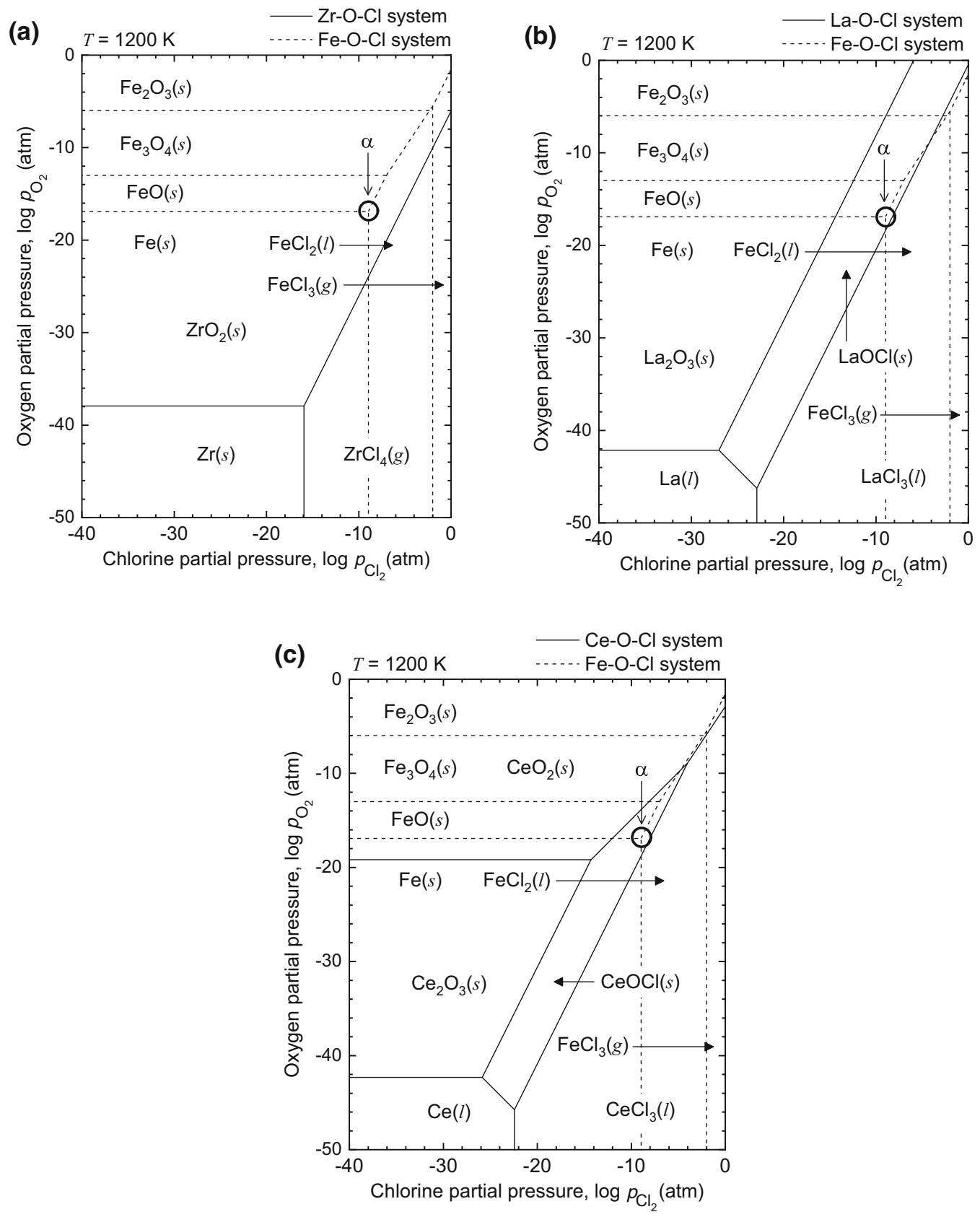

Fig. 7-Combined chemical potential diagrams of the (a) Zr-O-Cl and $\mathrm{Fe}-\mathrm{O}-\mathrm{Cl},(b) \mathrm{La}-\mathrm{O}-\mathrm{Cl}$ and $\mathrm{Fe}-\mathrm{O}-\mathrm{Cl}$, and $(c) \mathrm{Ce}-\mathrm{O}-\mathrm{Cl}$ and $\mathrm{Fe}-\mathrm{O}-\mathrm{Cl}$ systems constructed at $1200 \mathrm{~K}\left(927^{\circ} \mathrm{C}\right)$. The thermodynamic data reported in Refs. [23] and [27] were used. The potential point $\alpha$ corresponds to the Fe/ $\mathrm{FeCl}_{2} / \mathrm{FeO}$ equilibrium.

performed by X-ray fluorescence spectroscopy (XRF) using a JSX-3100RII (JEOL).

When the tested sample was a plate-type simulated catalyst, it was manually crushed and pulverized using an agate mortar after the treatment with $\mathrm{FeCl}_{2}$ vapor. Subsequently, magnetic separation was performed by hand using a handheld neodymium magnet $(\mathrm{Nd}-\mathrm{Fe}-\mathrm{B}$ alloy; diameter: $30 \mathrm{~mm}$, thickness: $15 \mathrm{~mm}$, surface magnetic flux density: $490 \mathrm{mT}$ ). The PGM concentrations in the obtained magnetic and nonmagnetic powders were determined by inductively coupled plasma-atomic emission spectrometry (ICP-AES) using an SPS3520UV (SII NanoTechnology). The procedure for preparing sample solutions for ICP-AES is described in detail elsewhere. ${ }^{[17]}$ In this study, the PGM concentration in the catalyst sample before processing $\left(C_{\text {cat }, i}\right.$ (mass pct), $i$ : $\mathrm{Pt}, \mathrm{Pd}$, or $\mathrm{Rh}$ ) was evaluated based on the masses and PGM concentrations in the magnetic and nonmagnetic powders as follows:

$$
C_{\text {cat }, i}=\left(C_{\mathrm{mag}, i} \times w_{\mathrm{mag}}+C_{\mathrm{nmag}, i} \times w_{\mathrm{nmag}}\right) / w_{\mathrm{cat}}
$$

Here $C_{\mathrm{mag}, i}$ and $C_{\mathrm{nmag}, i}$ are the PGM concentrations in the magnetic and nonmagnetic powders determined by ICP-AES, respectively; $w_{\text {mag }}$ and $w_{\text {nmag }}$ are the masses 


\begin{tabular}{|c|c|c|c|}
\hline Material & Form & $\begin{array}{l}\text { Purity or Conc. } \\
\text { (Mass pct) }\end{array}$ & Note \\
\hline $\mathrm{Pt}$ & Powder & 99.95 & $\begin{array}{l}\text { Supplied by Tanaka Kikinzoku Kogyo K.K. } \\
\text { Micrometer sized, gray color. }\end{array}$ \\
\hline $\mathrm{Pd}$ & Powder & $>99.98$ & $\begin{array}{l}\text { Supplied by Furuya Metal Co., Ltd. } \\
\text { Micrometer sized, gray color. }\end{array}$ \\
\hline $\mathrm{Rh}$ & Powder & $>99.9$ & $\begin{array}{l}\text { Supplied by Tanaka Kikinzoku Kogyo K.K. } \\
\text { Micrometer sized, gray color. }\end{array}$ \\
\hline Cordierite & Powder & $>95$ & $\begin{array}{l}\text { Supplied by Marusu Glaze Co., Ltd. } \\
\text { Product name: SS-200. }\end{array}$ \\
\hline $\mathrm{Al}_{2} \mathrm{O}_{3}$ & Powder & $>99.5$ & $\begin{array}{l}\text { Supplied by Wako Pure Chemical Industries, Ltd. } \\
\text { Alfa alumina. }\end{array}$ \\
\hline $\mathrm{ZrO}_{2}$ & Powder & 99.9 & Supplied by Kanto Chemical Co., Inc. \\
\hline $\mathrm{La}_{2} \mathrm{O}_{3}$ & Powder & $>98$ & Supplied by Wako Pure Chemical Industries, Ltd. \\
\hline $\mathrm{CeO}_{2}$ & Powder & $>99.5$ & Supplied by Kanto Chemical Co., Inc. \\
\hline $\begin{array}{c}\text { Simulated } \\
\text { catalyst }\end{array}$ & Plate & $\begin{array}{l}\mathrm{Pt} \sim 0.04 \\
\mathrm{Pd} \sim 0.04 \\
\mathrm{Rh} \sim 0.04\end{array}$ & $\begin{array}{l}\text { Self-prepared sample. A PGM-bearing catalyst layer was formed on an } \\
\text { alumina plate with dimension of approximately } 25 \times 25 \times 0.5 \mathrm{~mm} \text {. }\end{array}$ \\
\hline
\end{tabular}
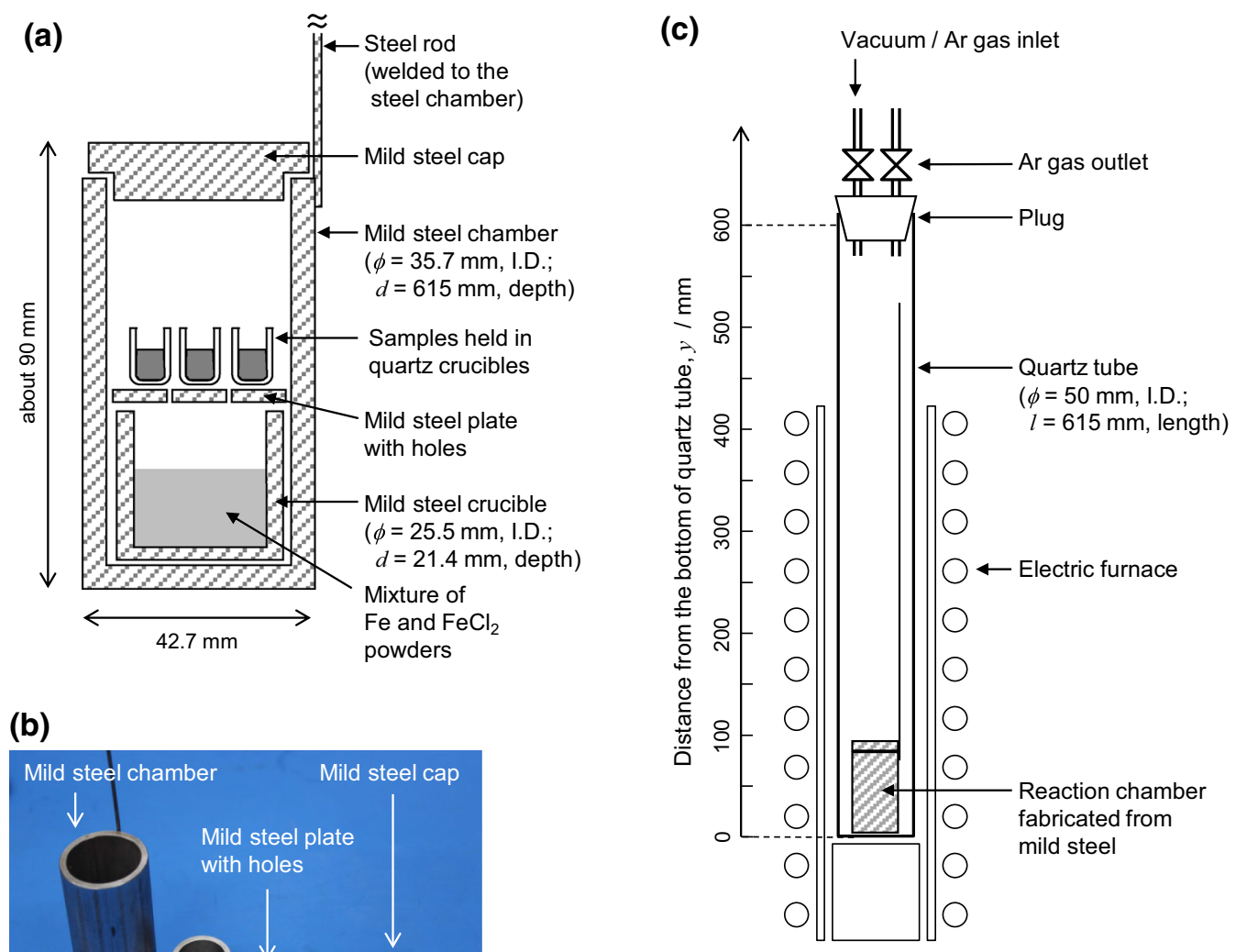

(b)

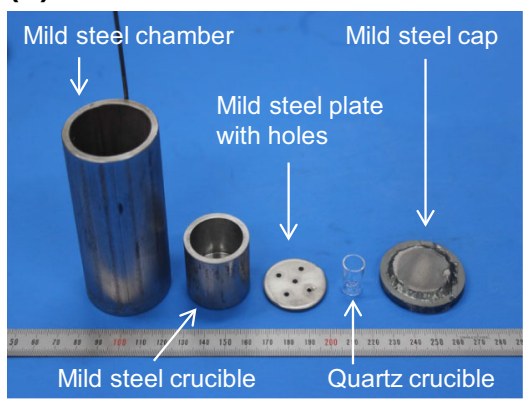

Fig. 8- (a) Schematic illustration of the reaction chamber and (b) a photograph of its parts before assembly. (c) Schematic illustration of the experimental apparatus used for the $\mathrm{FeCl}_{2}$ vapor treatment.

of the magnetic and nonmagnetic powders, respectively; and $w_{\text {cat }}$ is the mass of the catalyst sample before experiment. Furthermore, in order to evaluate the efficiency of the magnetic separation, the enrichment factor $\left(F_{i}\right)$ and recovery rate $\left(R_{i}\right.$ (pct)) of the PGMs were calculated as follows: 


\begin{tabular}{|c|c|c|c|c|c|c|}
\hline \multirow[b]{2}{*}{ Exp. No. } & \multirow[b]{2}{*}{$\begin{array}{c}\text { Mass of } \\
\mathrm{Fe} \\
w_{\mathrm{Fe}} / \mathrm{g}\end{array}$} & \multirow[b]{2}{*}{$\begin{array}{c}\text { Mass of } \\
\mathrm{FeCl}_{2} \\
w_{\mathrm{FeCl}_{2}} / \mathrm{g}\end{array}$} & \multirow[b]{2}{*}{ Processed Sample } & \multirow[b]{2}{*}{$\begin{array}{c}\text { Mass of the Sample } \\
\text { Before Vapor Treatment, } \\
w_{\mathrm{s} \text {, before }} / \mathrm{g}\end{array}$} & \multicolumn{2}{|c|}{ Experimental Results } \\
\hline & & & & & $\begin{array}{c}\text { Mass of the Sample } \\
\text { After Vapor Treatment, } \\
w_{\mathrm{s}, \text { after }} / \mathrm{g}\end{array}$ & $\begin{array}{l}\text { Weight } \\
\text { Change, } \\
X{\text { (pct })^{\mathrm{d}}}^{\text {Ch }}\end{array}$ \\
\hline A_150122-14 & 1.022 & 2.936 & $\begin{array}{l}\text { Pt powder } \\
\text { Pd powder } \\
\text { Rh powder }\end{array}$ & $\begin{array}{l}0.3997 \\
0.3759 \\
0.3844\end{array}$ & $\begin{array}{l}0.4959 \\
0.4749 \\
0.4761\end{array}$ & $\begin{array}{l}24 \\
26 \\
24\end{array}$ \\
\hline B_150119-10 $0^{\mathrm{b}}$ & 1.084 & 3.053 & $\begin{array}{l}\text { Cordierite powder } \\
\mathrm{Al}_{2} \mathrm{O}_{3} \text { powder }\end{array}$ & $\begin{array}{l}0.2837 \\
0.3139\end{array}$ & $\begin{array}{l}0.2909 \\
0.3142\end{array}$ & $\begin{array}{l}2.5 \\
0.1\end{array}$ \\
\hline$C_{-} 150122-15^{\mathrm{b}}$ & 1.001 & 3.031 & $\begin{array}{l}\mathrm{ZrO}_{2} \text { powder } \\
\mathrm{La}_{2} \mathrm{O}_{3} \text { powder } \\
\mathrm{CeO}_{2} \text { powder }\end{array}$ & $\begin{array}{l}0.3990 \\
0.4118 \\
0.4129\end{array}$ & $\begin{array}{l}0.4149 \\
0.6336 \\
0.5583\end{array}$ & $\begin{array}{l}4.0 \\
54 \\
35\end{array}$ \\
\hline $\begin{array}{l}\text { D_150629-16 } \\
\text { E_151024-18 }\end{array}$ & $\begin{array}{l}1.040 \\
1.025\end{array}$ & $\begin{array}{l}2.996 \\
5.996\end{array}$ & $\begin{array}{l}\text { Simulated catalyst } \\
\text { Simulated catalyst }\end{array}$ & $\begin{array}{l}1.434 \\
1.450\end{array}$ & $\begin{array}{l}1.453 \\
1.478\end{array}$ & $\begin{array}{l}1.4 \\
1.9\end{array}$ \\
\hline
\end{tabular}

(a)

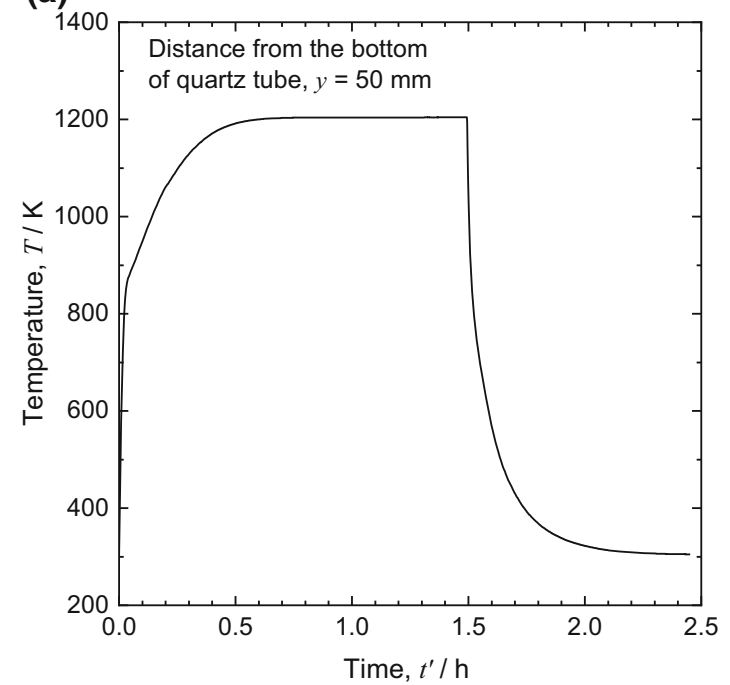

(b)

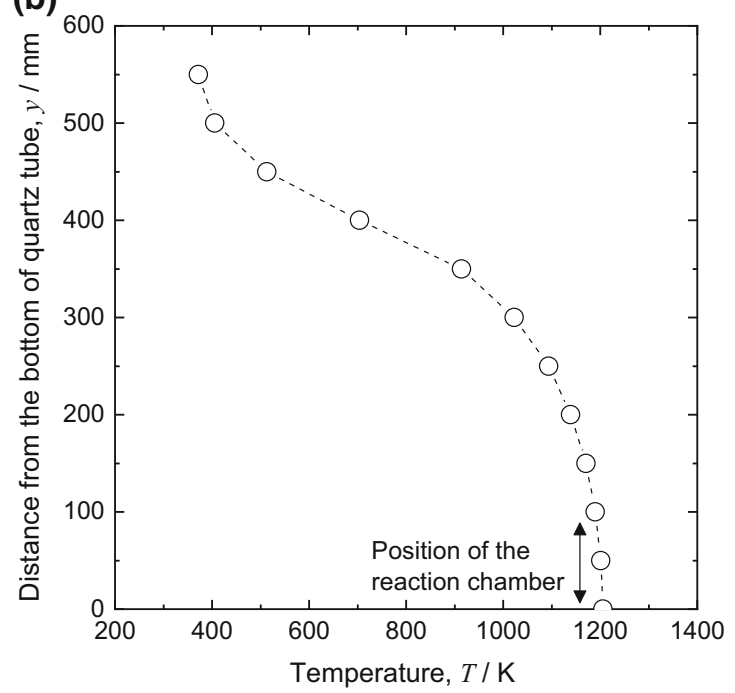

Fig. 9-Temperature profile inside the quartz tube during the $\mathrm{FeCl}_{2}$ vapor treatment. (a) Temperature change at the position of the steel reaction chamber. $(b)$ Temperature distribution inside the quartz tube when heating the reaction chamber at $1200 \mathrm{~K}\left(927^{\circ} \mathrm{C}\right)$.

$$
\begin{gathered}
F_{i}=C_{\mathrm{mag}, i} / C_{\mathrm{cat}, i} \\
R_{i}=100 \times\left(C_{\mathrm{mag}, i} \times w_{\mathrm{mag}}\right) /\left(\left(C_{\mathrm{mag}, i} \times w_{\mathrm{mag}}\right)\right. \\
\left.+\left(C_{\mathrm{nmag}, i} \times w_{\mathrm{nmag}}\right)\right) .
\end{gathered}
$$

\section{RESULTS AND DISCUSSION}

Figure 10 shows the quartz tube with the steel reaction chamber before and after the $\mathrm{FeCl}_{2}$ vapor treatment. After the heat treatment, $\mathrm{FeCl}_{2}$ disappeared from the chamber bottom, and white deposits identified as $\mathrm{FeCl}_{2}$ by XRD analysis were formed in the upper part of the quartz tube. This indicates that $\mathrm{FeCl}_{2}$ vapor was generated in the reaction chamber and diffused upward according to the temperature gradient inside the tube. Based on the visual observation of the upper part of the quartz tube during the heat treatment, the vaporization of $\mathrm{FeCl}_{2}$ was completed in approximately 1 hour from the start of the heat treatment procedure.

When PGM powders were treated with $\mathrm{FeCl}_{2}$ vapor, not only Pt, but also Pd and Rh particles were effectively alloyed with Fe. All PGM samples exhibited 


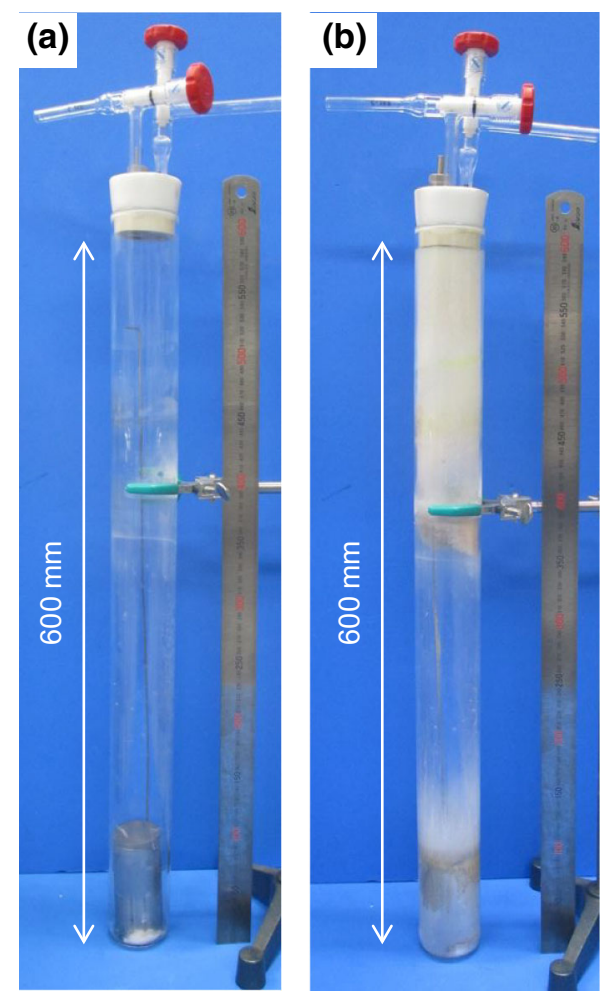

Fig. 10-A quartz tube with the steel reaction chamber $(a)$ before and $(b)$ after the $\mathrm{FeCl}_{2}$ vapor treatment (Exp. D_150629-16).

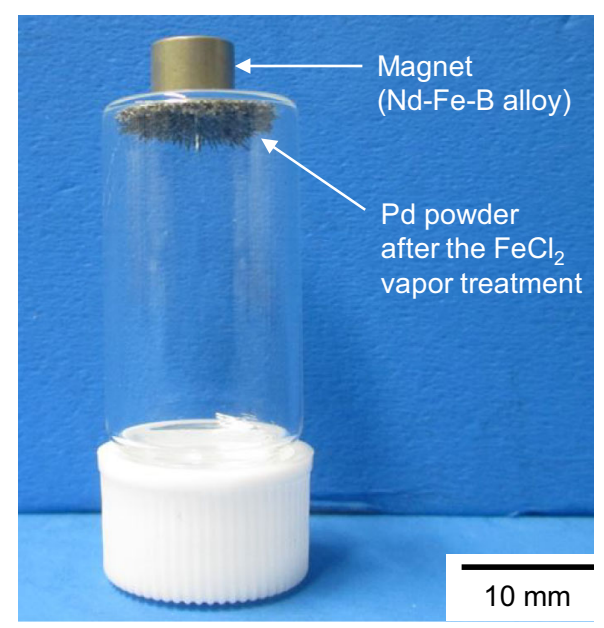

Fig. 11-A photograph of $\mathrm{Pd}$ powder obtained after the $\mathrm{FeCl}_{2}$ vapor treatment (Exp. A_150122-14).

ferromagnetic properties (Figure 11), and their masses increased by approximately 25 pct (Table II). Based on the weight increases, the obtained average compositions of $\mathrm{Pt}, \mathrm{Pd}$, and $\mathrm{Rh}$ powders after the vapor treatment were $\mathrm{Fe}_{0.46} \mathrm{Pt}_{0.54}, \mathrm{Fe}_{0.33} \mathrm{Pd}_{0.67}$, and $\mathrm{Fe}_{0.31} \mathrm{Rh}_{0.69}$, respectively (refer to the phase diagrams in Figure 4). The results of XRD analysis are shown in Figure 12, which suggest that $\mathrm{Pt}$ species were converted into the $\gamma_{2}-\mathrm{FePt}$ ferromagnetic phase. In the Pd sample, the $\gamma_{2}-\mathrm{FePd}_{3}$ ferromagnetic phase was formed after the vapor treatment. This means that Pd species were alloyed during

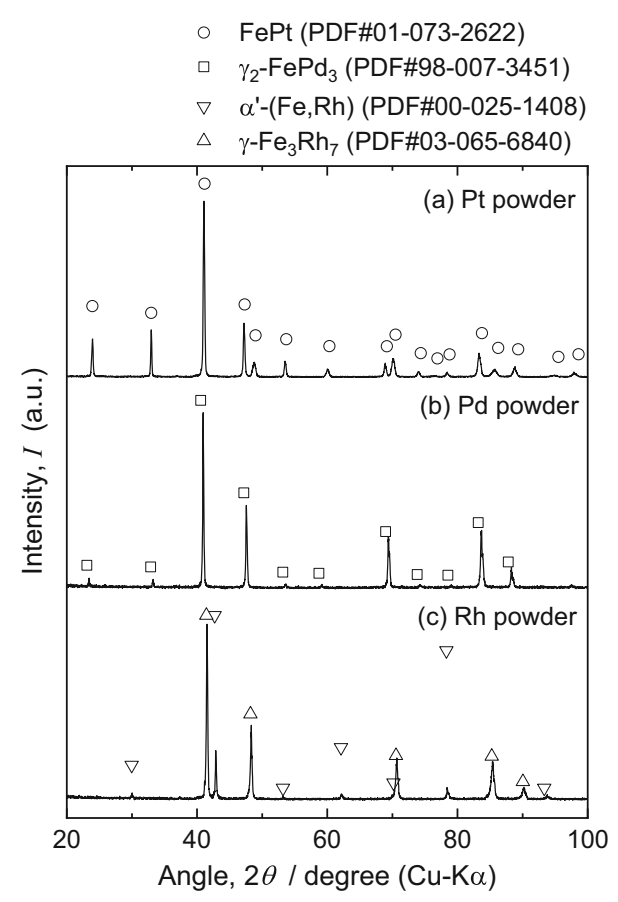

Fig. 12-XRD patterns of (a) Pt, (b) Pd, and (c) Rh powders recorded after the $\mathrm{FeCl}_{2}$ vapor treatment (Exp. A_150122-14).

the vapor treatment and that the transformation of $\gamma$-(Fe,Pd) (disordered face-centered cubic structure) to $\gamma_{2}-\mathrm{FePd}_{3}$ (ordered $\mathrm{L}_{2}$ structure) proceeded during cooling. The major phase of the Rh sample was the nonmagnetic $\gamma$-(Fe, Rh); however, the $\alpha^{\prime}-(\mathrm{Fe}, \mathrm{Rh})$ ferromagnetic phase was formed as well. This suggests that particles consisting of two phases of $\gamma-(\mathrm{Fe}, \mathrm{Rh})$ and $\alpha^{\prime}-(\mathrm{Fe}, \mathrm{Rh})$ were formed by the vapor treatment. Prolonged treatment should lead to increased alloying with $\mathrm{Fe}$ and an increase in the formation of ferromagnetic phases such as $\alpha^{\prime}$-(Fe, Rh).

Figure 13 shows the XRD patterns of cordierite, $\mathrm{Al}_{2} \mathrm{O}_{3}$, and $\mathrm{ZrO}_{2}$ powders recorded after the vapor treatment. XRD analyses indicated that these oxides remained unreacted, which was consistent with the thermodynamic considerations presented in Section II. The weights of cordierite and $\mathrm{ZrO}_{2}$ powders slightly increased after the treatment (see Table II), which might be attributed to the addition of a small amount of $\mathrm{FeCl}_{2}$ into the samples during their recovery from the reaction chamber after the heat treatment.

Figure 14 shows the XRD patterns of $\mathrm{La}_{2} \mathrm{O}_{3}$ and $\mathrm{CeO}_{2}$ powders after the vapor treatment. It is clear that both samples reacted with $\mathrm{FeCl}_{2}$ vapor to form oxychlorides, as was predicted by the thermodynamic analysis presented in Section II. When $\mathrm{La}_{2} \mathrm{O}_{3}$ and $\mathrm{CeO}_{2}$ are reacted according to reactions [5] and [6], respectively, $\mathrm{FeO}$ is formed as a byproduct. However, its presence was not detected by XRD in this study. The qualitative XRF analysis indicated that $\mathrm{La}_{2} \mathrm{O}_{3}$ and $\mathrm{CeO}_{2}$ powders contained $\mathrm{Fe}$ species after the vapor treatment. Therefore, it can be concluded that either the amorphous-like $\mathrm{FeO}$ phase or another phase was formed during the vapor treatment. According to reactions [5] and [6], the theoretical weight increases of $\mathrm{La}_{2} \mathrm{O}_{3}$ and 
- Cordierite, $\mathrm{Mg}_{2} \mathrm{Al}_{4} \mathrm{Si}_{5} \mathrm{O}_{18}$ (PDF\#00-012-0303)

- $\mathrm{Al}_{2} \mathrm{O}_{3}$ (PDF\#00-046-1212)

$\nabla \mathrm{ZrO}_{2}(\mathrm{PDF}$ 00-037-1484)

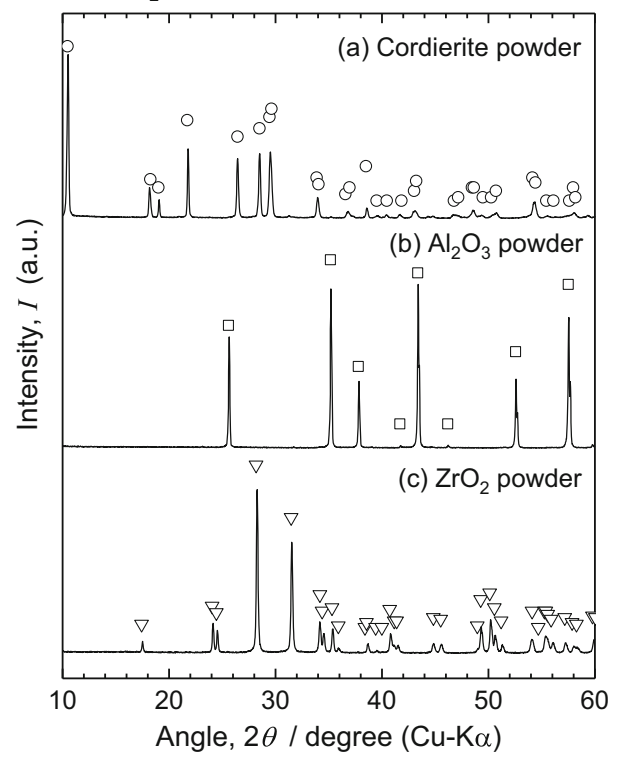

Fig. 13-XRD patterns of (a) cordierite, (b) $\mathrm{Al}_{2} \mathrm{O}_{3}$, and (c) $\mathrm{ZrO}_{2}$ powders recorded after the $\mathrm{FeCl}_{2}$ vapor treatment (Exp. B_150119-10 and C_150122-15).

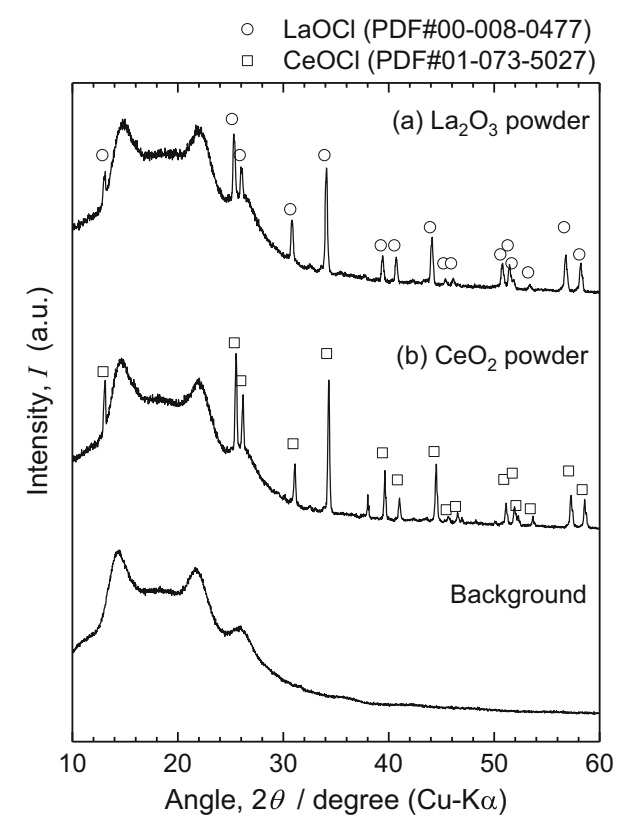

Fig. $14-\mathrm{XRD}$ patterns of $(a) \mathrm{La}_{2} \mathrm{O}_{3}$ and $(b) \mathrm{CeO}_{2}$ powders recorded after the $\mathrm{FeCl}_{2}$ vapor treatment (Exp. C 150122-15). The observed background profile originated from the polyimide film, which was used to cover the sample to prevent moisture absorption during measurements.

$\mathrm{CeO}_{2}$ powders are 61 and 53 pct, respectively. However, the experimental weight gains of these powders determined in this study were 54 and 35 pct, respectively (see Table II). This suggests that parts of the treated samples remained unreacted and/or changed into reaction intermediates because of the relatively short reaction time.
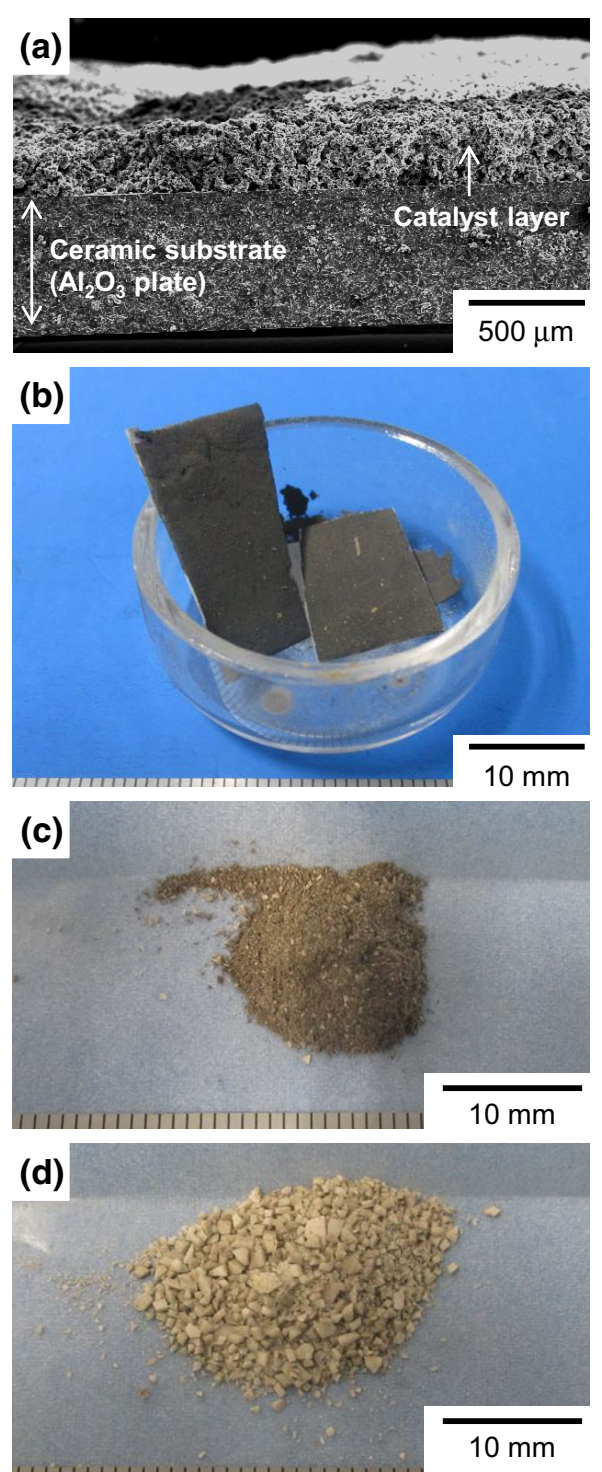

Fig. 15-(a) A cross-sectional SEM image of the catalyst sample reprinted with permission from a previous report Ref. [17]. Photographs of the $(b)$ catalyst sample after the vapor treatment and the $(c)$ magnetic and $(d)$ nonmagnetic powders recovered by magnetic separation (Exp. D_150629-16).

After the $\mathrm{FeCl}_{2}$ vapor treatment followed by pulverization, the catalyst samples were successfully separated into the magnetic and nonmagnetic powders, as shown in Figure 15. This indicates that the present PGM particles were effectively and selectively alloyed with $\mathrm{Fe}$. Table III lists the masses and compositions of these samples, while Table IV provides the corresponding enrichment factors and recovery rates of PGMs. The obtained results show that PGMs were successfully extracted from the catalysts samples and concentrated in the magnetic powder. The magnetic separation procedure increased the concentrations of $\mathrm{Pt}, \mathrm{Pd}$, and $\mathrm{Rh}$ by a factor of 3 to 5 , and the amounts of PGMs in the remaining nonmagnetic powders were negligible. The enrichment factor of PGMs achieved in this study was too low to be used in practical industrial applications. 
Table III. Masses and Compositions of the Simulated Catalysts Before and After Processing

\begin{tabular}{|c|c|c|c|c|c|c|c|c|c|c|c|c|}
\hline \multirow[b]{3}{*}{ Exp. No. } & \multicolumn{4}{|c|}{ Catalyst Sample } & \multicolumn{4}{|c|}{ Magnetic Powder } & \multicolumn{4}{|c|}{ Nonmagnetic Powder } \\
\hline & \multirow[b]{2}{*}{ Mass, $w_{\text {cat }} / \mathrm{g}$} & \multicolumn{3}{|c|}{$\begin{array}{l}\text { Conc. of Element } i \text {, } \\
C_{\text {cat }, i}\left(\text { Mass pct) }{ }^{\mathrm{a}}\right.\end{array}$} & \multirow[b]{2}{*}{ Mass, $w_{\mathrm{mag}} / \mathrm{g}$} & \multicolumn{3}{|c|}{$\begin{array}{l}\text { Conc.of Element } i \\
C_{\text {mag, } i} \text { (Mass pct) } \\
\end{array}$} & \multirow[b]{2}{*}{ Mass, $w_{\text {nmag }} / \mathrm{g}$} & \multicolumn{3}{|c|}{$\begin{array}{l}\text { Conc. of Element } i \text {, } \\
C_{\text {nmag, } i} \text { (Mass pct) }\end{array}$} \\
\hline & & $\mathrm{Pt}$ & $\mathrm{Pd}$ & $\mathrm{Rh}$ & & $\mathrm{Pt}$ & $\mathrm{Pd}$ & $\mathrm{Rh}$ & & $\mathrm{Pt}$ & $\mathrm{Pd}$ & $\mathrm{Rh}$ \\
\hline D_150629-16 & 1.434 & 0.041 & 0.039 & 0.041 & 0.449 & 0.13 & 0.12 & 0.13 & 0.993 & N.D. & 0.002 & N.D. \\
\hline E_151024-18 & 1.450 & 0.043 & 0.041 & 0.042 & 0.306 & 0.20 & 0.19 & 0.20 & 1.152 & 0.001 & 0.001 & N.D. \\
\hline
\end{tabular}

Table IV. Enrichment Factors and Recovery Rates of PGMs from the Simulated Catalyst Samples

\begin{tabular}{|c|c|c|c|c|c|c|}
\hline \multirow[b]{2}{*}{ Exp. No. } & \multicolumn{3}{|c|}{ Enrichment Factor of Element $i, F_{i}^{\mathrm{a}}$} & \multicolumn{3}{|c|}{ Recovery Rate of Element $i, R_{i}(\mathrm{pct})^{\mathrm{b}}$} \\
\hline & $\mathrm{Pt}$ & $\mathrm{Pd}$ & $\mathrm{Rh}$ & $\mathrm{Pt}$ & $\mathrm{Pd}$ & $\mathrm{Rh}$ \\
\hline D_150629-16 & 3.2 & 3.1 & 3.2 & $100^{c}$ & 96 & $100^{\circ}$ \\
\hline$E_{-}^{-} 151024-18$ & 4.7 & 4.6 & 4.8 & 98 & 98 & $100^{\mathrm{c}}$ \\
\hline
\end{tabular}

However, their magnitudes can be potentially improved by optimizing the pulverization and magnetic separation procedures.

The results obtained in this study indicate that the physical concentration pretreatment containing the $\mathrm{FeCl}_{2}$ vapor treatment and magnetic separation stages (Figure 1) is a feasible and effective technique for recovering PGMs directly from the catalyst scrap. The $\mathrm{FeCl}_{2}$ vapor treatment in the presence of metallic Fe can be used to convert PGMs ( $\mathrm{Pt}, \mathrm{Pd}$, and $\mathrm{Rh}$ ) in the catalyst scrap into ferromagnetic Fe-PGM alloys. During the alloying procedure, cordierite and $\mathrm{Al}_{2} \mathrm{O}_{3}$ species (i.e., major components of spent catalysts) remain unreacted. In contrast, $\mathrm{La}_{2} \mathrm{O}_{3}$ and $\mathrm{CeO}_{2}$ species, which are often contained in the catalyst layer of the automobile catalyst, react with $\mathrm{FeCl}_{2}$ vapor and reduce the amount of supplied $\mathrm{FeCl}_{2}$ species. However, the reaction products including rare-earth oxychlorides can be theoretically removed from the obtained PGM concentrates as nonmagnetic powders via magnetic separation.

\section{CONCLUSIONS}

In this study, a novel method for PGM extraction involving a pretreatment with $\mathrm{FeCl}_{2}$ vapor was demonstrated. The reactions of typical components of automobile catalysts (including $\mathrm{PGMs}$, cordierite, $\mathrm{Al}_{2} \mathrm{O}_{3}$, $\mathrm{CeO}_{2}, \mathrm{La}_{2} \mathrm{O}_{3}$, and $\mathrm{ZrO}_{2}$ ) with $\mathrm{FeCl}_{2}$ vapor in the presence of metallic $\mathrm{Fe}$ at a temperature of around $1200 \mathrm{~K}\left(927^{\circ} \mathrm{C}\right)$ were examined through thermodynamic analyses and experiments. It was found that the $\mathrm{FeCl}_{2}$ vapor treatment could effectively convert PGMs $(\mathrm{Pt}, \mathrm{Pd}$, and $\mathrm{Rh}$ ) into ferromagnetic alloys despite the absence of a physical contact with metallic Fe. Furthermore, cordierite, $\mathrm{Al}_{2} \mathrm{O}_{3}$, and $\mathrm{ZrO}_{2}$ did not interact with $\mathrm{FeCl}_{2}$ vapor, while $\mathrm{CeO}_{2}$ and $\mathrm{La}_{2} \mathrm{O}_{3}$ species were converted into their oxychlorides. During the fundamental testing of the samples simulating an automobile catalyst, PGMs were successfully concentrated by magnetic separation after the $\mathrm{FeCl}_{2}$ vapor treatment. Thus, it can be concluded that the proposed method is a feasible and useful technique for recovering PGMs directly from spent catalysts.

Although further studies are required for its practical implementation, the physical concentration process involving the $\mathrm{FeCl}_{2}$ vapor treatment can potentially increase the efficiency and throughput of the existing recycling processes when used during the pretreatment stage. Furthermore, because the proposed method does not require a large-scale plant, it can be performed at the collecting and scrapping sites for old automobiles. The automobile catalyst scraps collected at such sites are often transported to smelters by sea or by ground. However, if PGMs are concentrated directly at the collecting and scrapping sites, they can be transported by air to refineries for further treatment. Using this new recycling route, PGMs can be potentially recovered within a relatively short lead time.

\section{ACKNOWLEDGMENTS}

The authors are grateful to Dr. Katsuhiro Nose (The University of Tokyo, currently with JX Nippon Mining \& Metals Corporation), Mr. Tetsuo Watanabe (The University of Tokyo, currently with Tanaka 
Kikinzoku Kogyo K. K.), Dr. Takanari Ouchi, Mr. Ryohei Yagi, Mr. Akihiro Iizuka (The University of Tokyo) for their valuable suggestions and comments. The authors thank Marusu Glaze Co., Ltd. for providing cordierite powder. This research was financially supported by the Japan Society for the Promotion of Science (JSPS) through the Grant-in-Aid for Scientific Research (S) (KAKENHI Grant No. 26220910) and by the Mazda Foundation.

\section{REFERENCES}

1. PGM Market Report May 2017 Summary of Platinum Supply and Demand in 2016 (Johnson Matthey Plc., 2017), http://www. platinum.matthey.com/services/market-research/pgm-market-reports. Accessed 5 Dec 2017.

2. F. Habashi (ed.): Handbook of Extractive Metallurgy, VCH Verlagsgesellschaft mbH, Weinheim, 1997, vol. III, pp. 1269-26.

3. F.K. Crundwell, M.S. Moats, V. Ramachandran, T.G. Robinson, and W.G. Davenport: Extractive Metallurgy of Nickel, Cobalt and Platinum-Group Metals, Elsevier, Oxford, 2011.

4. S. Seetharaman (ed.): Treatise on Process Metallurgy, Volume 3: Industrial Processes, Elsevier, London, 2013, pp. 1071-97.

5. R.K. Mishra: Proceedings of the 17th International Precious Metals Conference, 1993, pp. 449-74.

6. S. Suzuki, M. Ogino, and T. Matsumoto: J. MMIJ., 2007, vol. 123, pp. 734-36 (in Japanese).

7. M. Benson, C.R. Bennett, J.E. Harry, M.K. Patel, and M. Cross: Resour. Conserv. Recycl., 2000, vol. 31, pp. 1-7.

8. H. Dong, J. Zhao, J. Chen, Y. Wu, and B. Li: Int. J. Miner. Process., 2015, vol. 145, pp. 108-13.

9. F.L. Bernardis, R.A. Grant, and D.C. Sherrington: React. Funct. Polym., 2005, vol. 65, pp. 205-17.

10. S. Owada, H. Seshimo, M. Miyashita, and K. Fujiwara: Proceedings of the 2nd International Symposium on East Asian Resources Recycling Technology, 1993, pp. 69-77.
11. S. Owada, Y. Tsubuku, and H. Nakayama: Proceedings of MMIJ Spring Meeting, 1994, pp. 282-83 (in Japanese).

12. S. Owada and K. Shinoda: Proceedings of MMIJ Spring Meeting, 2006, pp. 69-70 (in Japanese).

13. W. Kim, B. Kim, D. Choi, T. Oki, and S. Kim: J. Hazard. Mater., 2010, vol. 183, pp. 29-34.

14. G. Liu, T. Ichinose, A. Tokumaru, and S. Owada: Mater. Trans., 2015, vol. 55, pp. 978-85.

15. G. Liu, A. Tokumaru, and S. Owada: Resour. Process., 2013, vol. 60 , pp. $28-35$.

16. T.H. Okabe and J. Mitsui: Japan Patent, P5946034, 2016 (in Japanese).

17. Y. Taninouchi, T. Watanabe, and T.H. Okabe: Mater. Trans., 2017, vol. 58 , pp. $410-19$.

18. Y. Taninouchi, T. Watanabe, and T.H. Okabe: Metall. Mater. Trans. B., 2017, vol. 48B, pp. 2027-36.

19. Y. Taninouchi and T.H. Okabe: in Rare Metal Technology 2017 (Proceedings of the TMS 2017 Annual Meeting and Exhibition (TMS2017)), Springer, Cham, 2017, pp. 119-27.

20. Y. Taninouchi and T.H. Okabe: Mater. Trans., 2018, vol. 59, pp. 88-97.

21. Y. Danzaki and T. Ashino: Anal. Sci., 2001, vol. 17, pp. 1011-113.

22. H. Sasaki and M. Maeda: J. Phys. Chem. C., 2013, vol. 117, pp. $18457-63$.

23. I. Barin: Thermochemical Data of Pure Substance, 3rd ed., VCH Verlagsgesellschaft mbH, Weinheim, 1995.

24. P. Franke and D. Neuschütz (eds.): Binary Systems. Part 3: Binary Systems from Cs-K to $\mathrm{Mg}-\mathrm{Zr}$, Springer, Cham, 2005.

25. H. Okamoto (ed.): Phase Diagrams of Binary Iron Alloys, ASM International, Ohio, 1993.

26. P. Fredriksson and S. Seethraman: Scand. J. Metall., 2001, vol. 30, pp. 258-64.

27. D.D. Wagman, W.H. Evans, V.B. Parker, R.H. Schumm, I. Halow, S.M. Bailey, K.L. Churney, and R.L. Nuttall: J. Phys. Chem. Ref. Data., 1982, vol. 11.

28. T.H. Okabe, C. Zheng, and Y. Taninouchi: Metall. Mater. Trans. B., 2018, https://doi.org/10.1007/s11663-018-1172-4. 